\title{
Viral Marketing Berbasis Komunitas (Studi Kasus terhadap Dance Cover Playcrew)
}

\author{
Indra Ridwan Maulana, Sinta Paramita \\ Indra.915160220@stu.untar.ac.id, sintap@fikom.untar.ac.id
}

Fakultas Ilmu Komunikasi Universitas Tarumanagara

\begin{abstract}
Viral marketing is another form of word of mouth, or "news from one mouse click to the next click (word of mouse)." Which encourages consumers to tell products and services developed by the company or audio, video and written information to others online. In human community, the individuals within it can have intentions, beliefs, resources, preferences, needs, risks and a number of other similar conditions. The purpose of the research is to find out how community- based viral marketing (case study of Playcrew dance cover). This research is a qualitative research using a case study method. theories used in this research are Viral Marketing, Popular Culture, Advertising and Mass Communication, Community and Dance cover theories. This research uses interviews with key informants and informants, literature studies, and documentation for data collection. The results of this study are dance cover playcrew able to influence people to find out about the hallyu culture of South Korea.
\end{abstract}

Keywords: dance cover, dance cover community, popular culture, viral marketing

\begin{abstract}
Abstrak
Viral marketing adalah bentuk lain berita dari mulut ke mulut, atau "berita dari satu klik mouse ke klik berikutnya (word of mouse)." Yang mendorong konsumen menceritakan produk dan jasa yang dikembangkan perusahaan atau informasi audio, video, dan tertulis kepada orang lain secara online. Dalam komunitas manusia, individu- individu di dalamnya dapat memiliki maksud, kepercayaan, sumber daya, preferensi, kebutuhan, risiko dan sejumlah kondisi lain yang serupa. Adapun maksud dari penelitian tersebut untuk mengetahui bagaimana viral marketing berbasis komunitas (studi kasus terhadap dance cover Playcrew). penelitian ini merupakan sebuah penelitian kualitatif yang menggunakan metode studi kasus. teori yang digunakan dalam penelitian ini adalah teori Viral Marketing, Budaya Populer,Iklan dan Komunikasi Massa, Komunitas dan Dance cover. penelitian ini menggunakan metode wawancara dengan informan kunci dan informan, studi pustaka, dan dokumentasi untuk pengumpulan data. Hasil dari penelitian ini adalah dance cover playcrew mampu mempengaruhi masyarakat untuk mengetahui tentang budaya hallyu dari korea selatan.
\end{abstract}

Kata kunci: budaya popular, dance cover, komunitas dance cover, viral marketing

\section{Pendahuluan}

Fenomena K-Pop atau Korean Pop populer di dunia terutama sejak berbagai girlgroup dan boygroup asal Korea Selatan go international termasuk di Indonesia. KPop sangat populer di Indonesia. Sejak tahun 2011, banyak artis dari Korea Selatan yang datang ke Indonesia untuk mengadakan konser (Soraya, 2013). Sejak itu, muncul juga berbagai komunitas penggemar dari grup K-Pop yang diidolakan.

Masing - masing komunitas penggemar biasanya melakukan kegiatan yang berkaitan dengan idola mereka seperti mengadakan sebuah acara yang meliputi 
menonton video grup K-Pop idola mereka, merayakan ulang tahun anggota K-Pop idola, hingga menjual merchandise yang berkaitan dengan grup K-Pop idola mereka. Di samping itu, bentuk lain dari ekspresi penggemar terhadap K-Pop, yakni munculnya aktivitas Cover Dance K-Pop Aktivitas ini merupakan salah satu aliran populer dance yang dilakukan seseorang atau sekelompok orang dengan meniru koreografi dance dan fashion penampilan idola mereka. Di Indonesia juga sudah banyak kelompok maupun komunitas Cover Dance K-Pop. Bahkan sudah banyak yang mengikuti hingga menjuarai kompetisi tingkat internasional. Menurut peneliti, Cover Dance K-Pop bukan lagi penggemar yang menikmati musik K-Pop saja akan tetapi mereka sudah di tingkat dimana mereka dapat menghasilkan sebuah karya.

Penggemar yang terjun ke dunia Cover Dance memaksimalkan agar terlihat semirip mungkin dengan idola mereka. Dimulai dari gaya berpakaian, make up, dan ekspresi wajah ketika berada di atas panggung, ada yang tanpa sadar bahwa hal tersebut terbawa dalam kehidupan sehari-hari yang disebabkan oleh terlalu sering mereka berperan sebagai seorang Cover Dance.

Hal ini dapat dilihat dari berkembangnya budaya K-Pop yang sudah menyebar luas di Asia khususnya di Indonesia. Maksud dari budaya Korea disini adalah semua unsur yang semua bercirikan Korea, yaitu fenomena penyebarluasan budaya Korea secara global yang disebut K-Pop atau dalam bahasa Korea (Hallyu). Berdasarkan latar belakang tersebut, penulis melakukan penelitian dan menyusun penelitian ini untuk mengetahui tahapan viral marketing berbasis komunitas (studi kasus terhadap dance cover Playcrew).

Viral marketing adalah suatu teknik pemasaran dengan memanfaatkan kemajuan media elektronik untuk mencapai suatu tujuan yang ingin dicapai oleh marketer yang dilakukan melalui proses komunikasi secara terus menerus atau berantai dan memperbanyak diri. Konsep cara kerja dari viral marketing ini sendiri seperti layaknya sebuah penyebaran virus, yaitu memperbanyak dirinya sendiri. Seperti seorang konsumen yang puas dengan sautu produk yang mereka beli atau jasa yang meraka dapatkan, secara otomatis akan menyebarluaskan informasi atau produk tersebut kepada kerabat mereka untuk juga mencoba dan membuktikannya sendiri. Pemasaran dari mulut ke mulut yang diperkuat dengan efek dari jaringan sosial atau media sosial juga termasuk dalam viral marketing (Kotler, 2009).

\section{Metode Penelitian}

Penelitian ini menggunakan pendekatan penelitian kualitatif dengan menggunakan metode studi kasus agar mengetahui lebih jelas mengenai proses viral pada dance cover dalam penelitian ini yaitu Playcrew. Subjek dan objek penelitian ini adalah pendiri serta penggemar dance cover Playcrew, yaitu Edwin Grinaldi, Jemima Roselyn, Kevin Putra Lika, Audi Vessalius, Mega Rahmawati dan Siti Fatimah. Penulis menggunakan teknik pengambilan data dengan melakukan wawancara, studi pustaka, dan dokumentasi dalam penelitian ini.

\section{Hasil Temuan dan Diskusi}

Komunitas berasal dari bahasa latin communitas yang berarti "kesamaan", kemudian dapat diturunkan dari communis yang berarti "sama, publik, dibagi oleh semua atau banyak". Komunitas sebagai sebuah kelompok sosial dari beberapa organisme yang berbagi lingkungan, umumnya memiliki ketertarikan dan habitat yang 
sama. Dalam komunitas manusia, individu- individu di dalamnya dapat memiliki maksud, kepercayaan, sumber daya, preferensi, kebutuhan, risiko dan sejumlah kondisi lain yang serupa. Soenarno (2002), definisi komunitas adalah sebuah identifikasi dan interaksi sosial yang dibangun dengan berbagai dimensi kebutuhan fungsional.

K-Pop adalah kepanjangan dari Korean Populer (musik populer Korea) yang merupakan jenis musik populer yang berasal dari Korea Selatan. Jenis musik ini adalah jenis musik pop. Banyak artis dan kelompok musik populer yang berasal dari Korea Selatan dalam negeri dan populer di mancanegara. Kegandrungan musik K- Pop merupakan bagian yang tak terpisahkan dari demam K-Pop (Korean wave) di berbagai negara, termasuk Indonesia. K-Pop ada sejak tahun 1960-an, pengaruh dari musik J-Pop (Japan pop). Menurut pengamat musik Indonesia, yaitu Bens Leo, musik Korea bangkit karena adanya pengaruh dari kebangkitan J-Pop. Jika dalam beberapa waktu lalu musik Jepang bangkit dengan grup musiknya masing-masing, Korea bangkit dengan kekuatan grup vokal, baik boy band maupun girl band.

Bens Leo juga menjelaskan bahwa K-Pop sudah dipersiapkan sejak waktu lima tahun yang lalu karena Korea Selatan ingin mendapatkan pengakuan terhadap kebudayaan mereka. Musik Korea mempunyai dua unsur utama yaitu fashion dan musik itu sendiri. Biasanya musik korea mengusung musik dance, hip-hop, serta unsur koreografi dan kostum yang menarik. Disini keunggulan dalam ketampanan dan kecantikan juga ditonjolkan, selain kualitas pencipta musik oleh mereka sendiri.

Salah satu fitur utama Instagram yang kerap kali digunakan dalam kegiatan live shopping adalah Insta Story. Fitur ini memungkinkan para penggunanya untuk mengunggah foto maupun video dengan kurun waktu slide show 24 jam. Saat ini dance cover K-Pop bukan lagi sebatas hobi yang dilakukan untuk bersenangsenang. Kegiatan ini bahkan bisa menghasilkan pendapatan yang cukup signifikan bagi komunitas dance cover tersebut.

Gambar 1. Playboys Sub Unit Playcrew

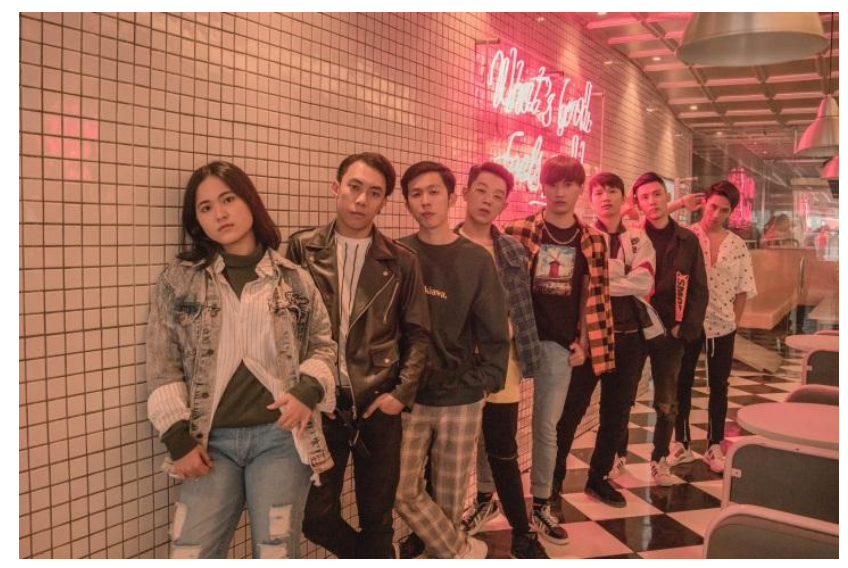

Sumber: Dokumentasi Pribadi (2019)

Dance cover merupakan sebuah hobi yang dituangkan anak - anak Indonesia yang menyukai musik K-Pop. Untuk menjadi cover dance bukan merupakan hal yang merugikan bangsa Indonesia, dikarenakan dengan menjadi cover dance, anak muda Indonesia tidak menjadi hancur, tapi bisa membawa nama baik Indonesia di negara lain (Kompasiana, 2020). 
Gambar 2. Tahapan Viral Marketing Dance Cover

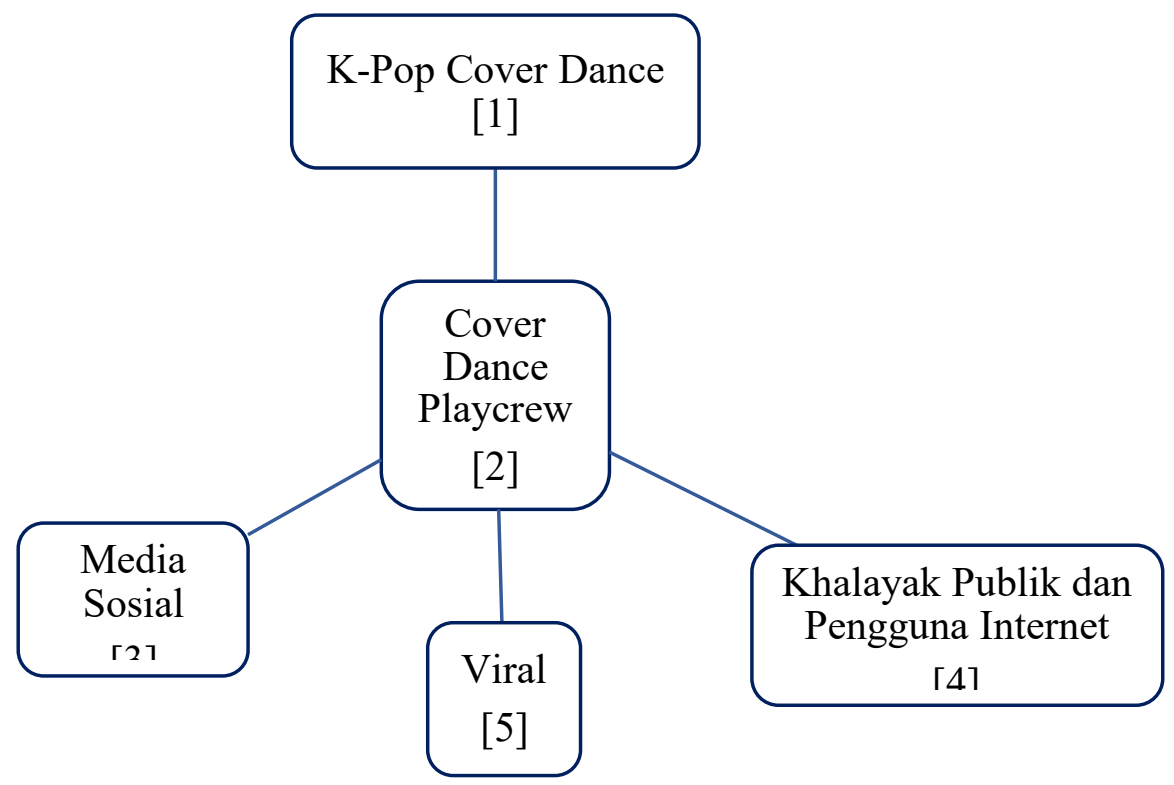

Sumber: Dokumentasi Pribadi (2020)

Dari tabel tersebut kita bisa mengetahui alur atau proses tahapan Viral Marketing pada suatu komunitas dance cover Playcrew berikut ini :

1. K-Pop Cover Dance: Merupakan sebuah kegiatan yang sudah ada sejak budaya Hallyu Korea Selatan masuk ke berbagai macam negara termasuk Indonesia. Kegiatan ini turun temurun dibudayakan oleh orang-orang yang menyukai budaya Hallyu atau biasa disebut K-Pop, yang membuat kegiatan ini terus berkembang pada awalnya dari mulut ke mulut dan juga melalui media Internet serta sosial media.

2. Cover Dance Playcrew : Sebuah komunitas atau grup cover dance yang sudah berdiri sejak tahun 2009 di mana semua anggotanya menyukai budaya Hallyu. Mereka tertarik untuk mengikuti fenomena yang sangat terkenal sekali dari dulu sampai saat ini yaitu meniru sekelompok idol atau yang biasa disebut Boyband dan Girlband asal Korea Selatan yang dinamakan K-Pop Cover Dance. Lalu mereka ingin menjadikan komunitas mereka dikenal oleh banyak masyarakat dengan cara memviralkan melalui media sosial yang ada seperti Instagram dan YouTube.

3. Media Sosial : Pada platform inilah komunitas cover dance Playcrew dan juga komunitas cover dance lainnya memanfaatkan media sosial sebagai jalan mereka agar menjadi terkenal dan dikenal oleh banyak masyarakat awam yang tidak mengetahui tentang budaya Hallyu asal Korea Selatan ini.

4. Khalayak publik dan pengguna internet: Pada bagian ini juga banyak masyarakat (khalayak publik) yang sudah menggunakan internet pada saat itu. mereka menggunakan internet untuk mencari tahu apa yang sedang viral pada perkembangan jaman saat ini, dari situ juga mereka pasti ingin tahu untuk mencari apa itu budaya Hallyu dan K-Pop Cover Dance.

5. Media sosial dan khalayak publik pengguna internet: dalam proses inilah media sosial dan khalayak publik pengguna internet saling menyebarluaskan tentang budaya Hallyu dan K-Pop Cover Dance sehingga bisa dikenal oleh masyarakat yang belum tahu akan hal tersebut. 
6. Viral: Proses inilah merupakan tahapan akhir. Terjadi Viral karena komunitas -komunitas dance cover Playcrew dan yang lainnya menggunakan media sosial sebagai platform untuk membuat komunitas mereka jadi dikenal orang dan pastinya bisa membuat mereka menjadi terkenal dengan fenomena K-Pop Cover Dance.

Menurut Armstrong dan Kotler (2004:90) Viral Marketing adalah: "Viral marketing is the Internet version of word-of-mouth marketing, that involves creating an E-Mail message or other marketing event that is so infectious that customers will want to pass it along to their friend". Kurang lebih dapat diartikan sebagai versi internet dari penggunaan pemasaran dari mulut ke mulut, yang sangat berhubungan dengan menciptakan e-mail atau acara pemasaran yang sangat menular sehingga pelanggan mau menyampaikannya kepada teman mereka.

Saat budaya populer K-Pop Cover Dance dari Korea Selatan semakin marak dan terkenal di Indonesia. Kegiatan ini juga sangat berpengaruh pada komunitaskomunitas K-Pop Cover Dance yang ada di Indonesia juga semakin naik daun atau menjadi viral, salah satunya adalah komunitas dance cover Playcew yang ikut merasakan komunitas mereka makin dikenal dimana-mana dan bahkan berbagai manca negara juga tahu akan komunitas cover dance Playcrew ini. Maka dari itu Playcrew semakin giat untuk menaikkan nama mereka di berbagai kalangan K-Popers yang ada di berbagai macam negara, yaitu dengan membuat konten video dance cover yang nantinya di sebar luaskan melalui media sosial seperti Instagram dan YouTube.

Gambar 2. Kata kunci Playcrew di YouTube

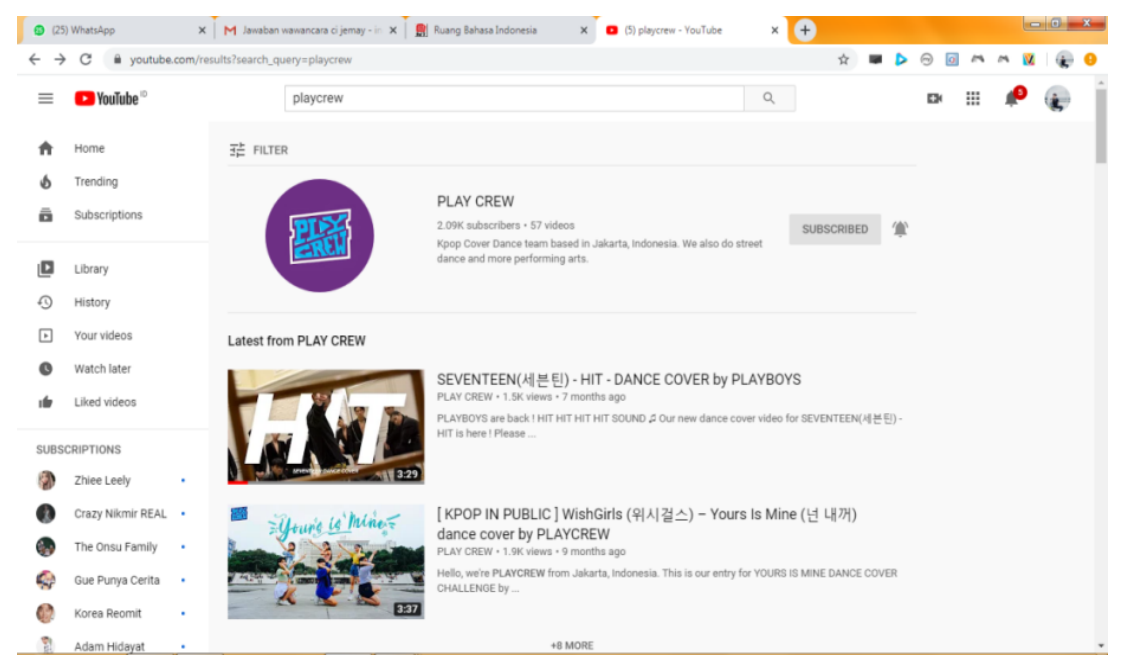

Sumber: Data Pribadi Screenshoot (2020)

Melalui YouTube juga semua penggemar K-Pop atau yang disebut dengan Hallyu dan juga perkembangan K-Pop Cover Dance yang ada di seluruh dunia termasuk Indonesia, yang dimana para penggemar juga bisa tahu komunitas dance cover apa saja yang sedang viral saat ini salah satunya adalah cover dance Playcrew dan juga masih banyak cover dance yang tentunya viral juga.

Pada YouTube juga terdapat banyak channel yang banyak membahas tentang K-Pop dance cover, seperti membuat konten menari di hadapan publik atau tempat yang memiliki pengunjung yang ramai. Disana beberapa komunitas K-Pop dance cover dapat mempromosikan grup dance cover mereka sendiri kepada masyarakat yang belum mengenal apa itu K-Pop dance cover. 


\section{Simpulan}

Terjadinya fenomena viral marketing pada saat ini begitu mudah apabila media dan pesan yang digunakan tepat. Kekuatan internet begitu berpengaruh ditengah perkembangan kecanggihan teknologi yang dikembangkan, beberapa waktu yang lalu viral marketing dapat terjadi apabila media yang digunakan seperti e-mail, aplikasi pengirim pesan, media sosial seperti Instagram dan juga youtube. Dimana semua orang bisa dengan leluasa untuk mengakses dan membuat konten pada media tersebut.

YouTube merupakan salah satu media sosial yang bersifat terbuka atau umum yang dimana semua orang bisa mengaksesnya dengan mudah, serta YouTube juga menyediakan berbagai macam konten yang disediakan bagi masyarakat pengguna sebagai saran menyalurkan hobi mereka.

\section{Ucapan Terima Kasih}

Saya sebagai peneliti ingin mengucapkan banyak terima kasih kepada seluruh narasumber penulis yang telah memberikan informasi terkait dengan penelitian ini. Lalu kepada keluarga, sahabat, dan teman - teman penulis yang ikut menyemangati dan memberikan banyak dukungan dalam penulisan skripsi ini.

\section{Daftar Pustaka}

Ajeng T. (2013). Komunikasi Nonverbal Mahasiswa Melalui Kegiatan "Cover Dance” Sebagai Penggemar Aliran Musik K-Pop (Studi Deskriptif Tentang Komunikasi Nonverbal Mahasiswa Melalui Kegiatan "Cover Dance” Sebagai Penggemar Aliran Musik K-pop Dalam Menunjukan Eksistensi Dirinya di Kota Bandung). Maret 25, 2020. Universitas Komputer Indonesia: Bandung.

Cover Dance dari Indonesia Berhasil Viral Karena Mirip Banget dengan Stray Kids. (2020). https://www.kapanlagi.com/korea/cover-dance-dari-indonesia-berhasilviral-karena-mirip-banget-dengan-stray-kids-250ac5.html

Emzir. (2016). Metodologi Penelitian Kualitatif: Analisis Data. Jakarta: Rajagrafindo Persada.

Hamzah, I. F. (2019). Pengalaman Menulis pada Penulis nonfiksi: sebuah wawancara online kualitatif. Prosiding Seminar Nasional Magister Psikologi Universitas Ahmad Dahlan. (2019). Mei, 18, 2020. http://seminar.uad.ac.id/index.php/snmpuad/article/view/3426

Kompasiana. (2020)

Sumber:

https://www.kompasiana.com/andzjjlin/555470036523bda6144aefc1/serunyamenjadidance-cover-kpop/ diakses pada 12 Mei 2020 pukul 18:27.

Moleong, L. J. (2018). Metodologi Penelitian Kualitatif (Edisi Revisi). Bandung: PT Remaja Rosdakarya.

Potensi Bisnis dari Komunitas Dance Cover K-Pop. (2020). https://kumparan.com/kumparank-pop/potensi-bisnis-dari-komunitas-dancecover-k-pop

Ruliana, P. (2014). Komunikasi Organisasi: Teori dan Studi Kasus. Jakarta: PT Rajagrafindo Persada.Bungin. Burhan. (2010). Penelitian Kualitatif: Komunikasi, 
Indra Ridwan Maulana, Sinta Paramita: Viral Marketing Berbasis Komunitas (Studi Kasus terhadap Dance Cover Playcrew)

Suka Duka Para Fans yang Tergabung dalam Komunitas K-Pop Dance Cover. (2020). https://kumparan.com/kumparank-pop/suka-duka-para-fans-yang-tergabung dalam-komunitas-k-pop-dance-cover

Yelly A, (2017). Pengaruh Konten Video dance K-Pop di YouTube terhadap komunitas cover dance di Bandar Lampung unruk melakukan cover dance KPop. 